\title{
Criminal Law and Republican Liberty: Philip Pettit's Account
}

\section{Jeremy Horder ${ }^{1}$ (D)}

Accepted: 15 March 2021

(C) The Author(s) 2021

\begin{abstract}
Philip Pettit has made central to modern republican theory a distinctive account of freedom-republican freedom. On this account, I am not free solely because I can make choices without interference. I am truly free, only if that non-interference does not itself depend on another's forbearance (what Pettit calls 'formal' freedom). Pettit believes that the principal justification for the traditional focus of the criminal law is that it constitutes a bulwark against domination. I will, in part, be considering the merits of this claim. Is the importance of the orthodox realm of the criminal law solely or mainly explained by the wish to protect people from domination? In short, the answer is that it is not. Across the board, the criminal law rightly protects us equally from threats to what Pettit calls 'effective,' as opposed to formal, republican freedom. I will develop my critique of Pettit's account of criminal law, in part to raise questions about the role of 'domination' in political theory, and about whether it poses a significant challenge to liberal accounts of criminal law.
\end{abstract}

Keywords Criminal law theory $\cdot$ Republican freedom $\cdot$ Formal freedom $\cdot$ Effective freedom $\cdot$ Nondomination

\section{Understanding Freedom as Non-domination}

According to a long-standing scholarly tradition, the functions of the criminal law are best understood in the broader context of state institutionalisation of (the threat of) coercion. Within this context, criminal law has a place within a relatively wideranging domain: loosely, the formal characterisation by the state and its agencies of types of doing or omission that are to be subjected to the threat of sanctions (or

\footnotetext{
I am very grateful to Doug Husak, and to the anomymous referees, for helpful comments on earlier drafts of this paper.

Jeremy Horder

J.Horder@1se.ac.uk

1 Department of Law, London School of Economics, Houghton Street, London WC2A2AE, UK
} 
other coercive measures). That domain goes well beyond a textbook concern-some might say, obsession - with wrongs that can be subjected to jury trial. The focus on the state's formalised threat of coercion means that the domain may extend as far, for example, as proceedings taken by an Insolvency Service against company directors, aimed at securing their disqualification for wrongful trading. ${ }^{1}$

In that regard, as Niki Lacey observes:

Criminal law's meaning as a system of quasi-moral judgement exists alongside its status as a regulatory or even administrative system, and the relationship between these two aspects of criminal law is arguably one of the most important keys to understanding its operation and development. ${ }^{2}$

However, until relatively recently, a proper appreciation of this important point was not to be found in many modern theoretical accounts of criminal law, whether given by criminal lawyers themselves, or by legal and political philosophers when speaking of the criminal law. I will consider here one such account, that of Philip Pettit, whose influential but narrow understanding of the criminal law runs counter to the contextualised account just outlined. In that regard, as we will see, his failure to adequately integrate regulatory offences centrally into his theory of criminal law is instructive, because it points to deeper difficulties with his 'republican' theory, as a critique of liberal theory.

Pettit has made central to modern republican theory a distinctive account of freedom-republican freedom. On this account, I am not free solely because I can make choices without interference. I am truly free, only if that non-interference does not itself depend on another's forbearance. To be worth having, my freedoms must not be at the mercy of some other person, even someone kindly disposed towards me. ${ }^{3}$ This is not an anarchistic or anti-authoritarian theory. Someone (X) may, perfectly legitimately, have power over another person (Y) in the republican state; but the legitimacy of the power turns on whether the choices $\mathrm{X}$ can make for Y must, "track the avowed or readily avowable interests of the other [or whether]...X can interfere according to their own arbitrium or decision. ${ }^{4}$ To avoid domination in the use of his or her power, $\mathrm{X}$ must also avoid using it to impose, 'alien ideas or interests' on $\mathrm{Y}^{5}$

\footnotetext{
1 See Company Directors Disqualification Act (UK) 1986. A broad characterisation of this kind is accepted even by those adopting a more philosophical than social scientific approach to criminal law. See Antony Duff, 'Responsibility and Criminal Law: Comments on Vincent Chiao, Criminal Law in the Age of the Administrative State, Chapter 7' (2018) 17(1) Jerusalem Journal of Legal Studies 128, 129, 'criminal law is concerned with various types of undesirable conduct; and although part of its role is to define those types of conduct ex ante, as to be avoided, it also functions ex post, as providing a distinctive kind of response to those who nonetheless engage in such conduct.'.

2 Nicola Lacey, "Philosophical Foundations of the Criminal Law": Social not Metaphysical', in Jeremy Horder (ed), Oxford Essays in Jurisprudence $4^{\text {th }}$ Series (Oxford: Oxford University Press, 2000), 17, at 27.

3 Philip Pettit, 'Criminalisation in Republican Theory', in RA Duff et al., Criminalisation: The Political Morality of the Criminal Law (Oxford: Oxford University Press, 2014), ch 5.

4 Philip Pettit, 'Keeping Republican Freedom Simple: On a Difference with Quentin Skinner' (2002) 30 Political Theory 339, at 342.

5 Philip Pettit, 'Republican Theory and Criminal Punishment' (1997) 9 Utilitas 60, at 61.
} 
Pettit illustrates his republican conception of freedom by reference to the difference in status of a slave, who is for whatever reason not currently controlled by a master ('servus sine domino'), and a person whose status means that they may not be subjected to the will of another at all (the 'liber'):

The liber may be unfortunate enough to suffer a great deal of interference and the servus sine domino may be lucky enough, or cunning or fawning enough, to avoid such interference. But the liber is nonetheless the free one among the two, for freedom is determined not by fortune but by the standing that one has within the community, and especially before the law. To be a free person, to be a liber, is to be in a position to call the law out against anyone who interferes or tries to interfere; it is to have the backing of the law against such interference, whether the threat comes from other private individuals or from the officials of the state itself. The servus sine domino lacks that protected status, even if the servus manages to escape interference. And so the servus is not free. ${ }^{6}$

The 'liber' enjoys a uniquely important freedom that Petit calls freedom as 'nondomination, ${ }^{7}$ a freedom as important in relations between lower-level state officials and citizens, and as between private citizens, as it is between national governments and citizens. ${ }^{8}$ Blackstone himself warned of the risk to personal liberty from the existence of powers of domination, even though he ultimately acknowledged the need for such powers:

Of great importance to the public is the preservation of this personal liberty; for if once it were left in the power of any the highest magistrate to imprison arbitrarily whomever he or his officers thought proper...there would soon be an end of all other rights and immunities. ${ }^{9}$

The scope of domination is narrow in significant respects. For example, according to Pettit, one cannot exercise domination accidentally or even (merely) knowingly. The exercise of domination must be 'intentional. ${ }^{10}$ Freedom from intentional domination is what Pettit refers to as, 'formal republican freedom.' ${ }^{11}$ Such limits to the wrong of domination - the denial of formal freedom — bring to mind critiques of the sociological analysis of the exercise of power in terms of intentional action. ${ }^{12}$ If D generally gets his way because people fear his ferocious appearance, or are drawn to his charisma, D will not be getting his way through an exercise of domination (on Pettit's account), unless D is intentionally using these characteristics to that end.

\footnotetext{
${ }^{6}$ Phillip Pettit, The Common mind: an Essay on Psychology, Society and Politics (Oxford: Oxford University Press, 1996), at 311.

7 Philip Pettit, n. 3, at 136.

8 Philip Pettit, n. 3 above, at 139.

9 Sir William Blackstone (1765), Commentaries on the Laws of England (Oxford: Clarendon Press, 1765), vol I, at 98.

10 Philip Pettit, n. 4 above, at 342-43.

11 Philip Pettit, n. 4 above, at 343.

12 Stephen Lukes, Power: A Radical View (Basingstoke: Palgrave Macmillan, 2005), first published in 1977.
} 
Analogously, suppose that people in social class B simply believe themselves to be inferior to people in social class A, and for that reason defer to the latter. In such a situation, those in social class A may be able to exercise substantial-and perhaps unjustified-control over the lives of those in social class B, without the intentional use of domination in Pettit's sense.

Real enough though the distinction may be between intentional and (merely) knowing control or power over others, we might pause to ask whether Pettit does enough to explain why the distinction should dictate the moral orientation of a political-or legal-theory. Should we not be equally concerned with all unjustified and avoidable threats to some people's autonomy, stemming from control or power possessed by other people? For such reasons, Vincent Chiao argues, 'Pettit's ideal of non-domination is best understood as a response to people standing in relations of subordination or social inferiority rather than sheer subjection to the unconstrained will of others. ${ }^{13}$ We will encounter this issue again in due course, but before moving on, we must consider the other dimension to Pettit's theory of freedom, effective republican freedom.

It is important to note that it is not Pettit's claim that the absence of formal republican freedom, domination, is the only significant social or political ill liable to befall someone over the life course. For Pettit, of lesser importance, but still significant, is, 'effective republican freedom' (alongside formal freedom). ${ }^{14}$ Effective republican freedom exists when, to an adequate degree, one does not face (or is adequately insulated from the deleterious effects of) unintentional obstacles to, 'uninterferedwith choice.' 15 Such unintentional obstacles include 'poverty, ill health, handicap or lack of talent, or obstacles that are unintended effects of what others do. ${ }^{16}$ An ingrained sense of social inferiority would fall into this category, as a form of unintentional obstacle. In the example just given, social class B could be said to lack effective republican freedom, even if they did not lack formal republican freedom.

Pettit purports to follow classical Roman exponents of republican thinking, in suggesting that it is other-things-being-equal worse to be subject to domination (but to be free from unintentional obstacles to free choice), than it is to be assailed by unintentional obstacles to free choice (but free from domination), although the minimisation of unintentional obstacles is morally and politically important. ${ }^{17}$ That is because unintentional obstacles to free choice are just obstacles, and not the supposedly more serious challenge of 'interference' in one's chosen life. Pettit would share the sentiment inspiring Chief Sitting Bull's famous words, 'Now that we are poor, we are free. No white man controls our footsteps.'

Pettit seeks to illustrate his thesis through a criminal law example. To suffer physical harm from an assault is (he thinks) to suffer harm from domination by the

\footnotetext{
13 Vincent Chiao, 'Discretion and Domination in Criminal Procedure: Reflections on Pettit' (2015) 15 Politics, Philosophy and Economics 92, at 101.

14 Philip Pettit, n. 4 above, at 343.

15 Ibid.

16 Ibid.

17 Ibid.
} 
criminal. By contrast, suppose one suffered the same kind of physical harm in some kind of accident-even an accident caused by gross negligence. Then, the harm would not have been brought about by domination, and it is the presence of domination, 'that explains why, intuitively, it is worse to have one's choices reduced by crime than by an unintended, perhaps purely natural, accident. ${ }^{18}$ The use of this example is significant, because Pettit believes that the principal justification for the criminal law is as a bulwark against domination. He says:

[C]riminal law will serve to establish the protections that each can expect to enjoy against particularly egregious forms of dominating interference that any others may seek to practise against them. ${ }^{19}$

I will be considering the merits of this claim. Is the criminal law, or at least the part of it with which Pettit concerns himself, ${ }^{20}$ solely or mainly driven by the wish to protect people from domination? In short, the answer is that it is not, even though there are some instances in which it provides such protection. The criminal law protects us equally -if not more so-from threats to effective republican freedom.

The descriptive difficulties faced by Pettit's theory, as it applies to the criminal law, mirror a broader worry about his thesis (alluded to above) considered as a political theory. The idea that domination is wrong is familiar to a number of thinkers in the twentieth century liberal tradition. For example, as John Finnis rightly observed nearly 40 years ago:

Individuals can only be 'selves' - i.e. have the 'dignity ' of being 'responsible agents' - if they are not made to live their lives for the convenience of others but are allowed and assisted to create a subsisting identity across a 'lifetime. ${ }^{21}$

However, by way of contrast with Pettit, writers in the liberal tradition do not mark out the wrong of domination for special condemnation, or argue that the law's most powerful deterrent and retributive tool-the criminal law-should be especially concerned with it, even though such writers recognise the distinction between formal and effective republican freedom on which Pettit draws. Instead, liberal thinkers-driven by an overriding concern for the conditions in which autonomy flourishes-are more apt to take equally seriously threats to what Pettit calls effective republican theory.

\footnotetext{
18 Ibid., at 344.

19 Philip Pettit, n. 3, at 139.

20 Pettit concern is a 'textbook' concern with offences against the person and property etc., and not with the vast bulk of criminal law, in the form of regulatory offences.

21 John Finnis, Natural Law and Natural Rights (Oxford: Clarendon Press, 1980), at 272.
} 


\section{Domination in the Bureaucratic State}

The criminal law is part of a criminal justice system that is largely founded on discretionary powers, many of which will possess the structural features of -will be-powers to dominate the lives of others. ${ }^{22}$ Even so, in the reasonably just state, such powers will fall outside the scope of Pettit's prohibition on domination. That is because, in such a state, it will not be possible to exercise such powers lawfully without an overriding regard to the public interest. In particular, it will never be lawful to exercise such powers merely to suit the convenience, wishes or 'arbitrium ${ }^{\text {,23 }}$ of the power-holder.

It is possible to think of instances in which self-serving considerations may enter into decisions made in the exercise of discretionary powers. A police officer might, for example, delay for a short time arresting a suspect until it stops raining, purely so that the officer will not get wet in making the arrest. Such a self-serving use of a discretion would be lawful, on Pettit's republican account of the limits on public power, only so long as it was clear that the public interest would not be affected by the delay (and so long as this consideration features in the officer's reasoning, as he or she shelters indoors). Having said that, if this was all there was to Pettit's theory, it would not amount to much. It would be purely negative in content: a prohibition on the use of powers over others for (purely) self-serving reasons. That Pettit's theory goes beyond this can be seen if we re-consider the passage cited at the outset.

In a state free from domination, a citizen's legal standing is crucial. He or she must be, 'in a position to call the law out against anyone who interferes or tries to interfere. ${ }^{24}$ The citizen must have the backing of the law against interference, "whether the threat comes from other private individuals or from the officials of the state itself. ${ }^{, 25}$ That suggests Pettit has a wider-ranging objection to discretionary powers as such. Someone cannot so easily 'call the law out' against interference, if the determination of what the law permits (in terms of interference) itself turns on a discretionary assessment by a legal official, whether that assessment is driven by self-serving or entirely by public interest-centred considerations. A legal system largely characterised by wide-ranging discretionary powers in the hands of officials is inimical to what Pettit calls the 'resilient property' of non-interference by the state. ${ }^{26}$ In a state that protects such non-interference, as Pettit frequently puts it:

\footnotetext{
${ }^{22}$ Nicola Lacey, 'In Search of the Responsible Subject: History, Philosophy and Social Sciences in Criminal Law Theory' (2001) 64 Modern Law Review 350, 356. See also Jeremy Horder (ed), Ashworth's Principles of Criminal Law $\left(9^{\text {th }}\right.$ edition, Oxford 2019), ch 1.

${ }^{23}$ See text at n. 4 above.

${ }^{24}$ See text at $n .6$ above.

${ }^{25}$ See text at $\mathrm{n} .6$ above.

${ }^{26}$ Philip Pettit, 'Negative Liberty, Liberal and Republican' (1993) 1 European Journal of Philosophy 15, at 16.
} 
[F]ree persons can walk tall, and look each other in the eye....[T]hey relate to one another in a shared, mutually reinforcing consciousness of enjoying this independence. ${ }^{27}$

Pettit's stance is reminiscent of the push back against discretionary powers given prominence in early twentieth century England by Lord Hewart, when he was Lord Chief Justice. ${ }^{28}$ Pettit's stance appears naïve for the same reasons. It is long established that officials exercising discretionary powers-at many different levels within the state apparatus - may be wrong to decide as they do, yet (being within the bounds of reasonableness) still be justified even when, say, they prioritise bureaucratic concerns over those of an individual citizen. ${ }^{29}$ This is a commonplace legal proposition. As long ago as 1933, in his famous critique of Lord Hewart's courtfocused legalism, John Willis said:

It has always been difficult, and with the increasing scope of Governmental interference it has become almost an impossibility, to discriminate between a legislative and a so-called administrative discretion. ${ }^{30}$

Commonplace though such remarks may be, they are hard to square with Pettit's emphasis on the ubiquitous need for citizens, vis-à-vis officials as well as each other, 'to... walk tall, and look each other in the eye [not depending] on anyone's grace or favour for being able to choose their mode of life. ${ }^{31}$

In fact, flourishing democratic-bureaucratic states do seek to encourage the important public good described by Pettit in the passage just cited, but not—as Pettit would seemingly have us do-by reducing the scope for discretionary decision-making. Instead, they seek to do it through shaping the values that infuse the exercise of such decision-making, and by making those values open to public scrutiny and critique. To give a criminal law example, an adult seeking assistance to commit suicide must rely on a favourable exercise of prosecutorial discretion by the prosecution services, if he or she is to avoid involving those providing the assistance in serious criminal activity. ${ }^{32}$ That puts him or her in a position of legalised domination, with respect to the prosecution authorities. Yet, the basis on which prosecutorial discretion must be exercised has been the subject of judicial guidance, public scrutiny and debate. ${ }^{33}$ It is by no means obvious that this position is worse than a state of affairs

\footnotetext{
${ }^{27}$ Philip Pettit, n. 3 above, at 138.

${ }^{28}$ Lord Hewart, The New Despotism (London: Ernest Benn, 1929).

${ }^{29} R v$ Port of London Authority Ex Parte Kynoch Ltd (1919) 1 KB 176; British Oxygen Company Ltd v Board of Trade [1971] AC 610. These cases set the terms of rational bureaucratic engagement: developing general policy to cover the bulk of cases, whilst remaining open to the possibility that an individual case might have to be treated differently.

${ }^{30}$ John Willis, The Parliamentary Powers of English Government Departments (Cambridge, Mass; Harvard 1933), at 47. See further, Jeremy Horder, 'Excusing Information-Provision Crimes in the Bureaucratic State' [2015] 68 Current Legal Problems 197.

${ }^{31}$ Philip Pettit, n. 3 above, at 138.

${ }^{32} \mathrm{R}$ (on the application of Pretty) v Director of Public Prosecutions [2001] UKHL 61.

${ }^{33} \mathrm{https} / / /$ www.cps.gov.uk/legal-guidance/policy-prosecutors-respect-cases-encouraging-or-assistingsuicide.
} 
in which domination is in theory eliminated, in that all cases of assisted suicide are prosecuted, or alternatively, in which the practice of assisted suicide is legalised in an unrestricted way. ${ }^{34}$

There have been attempts, on the part of some courts and liberal scholars, to conceive of the substantive criminal law in more republican terms, in Pettit's formal sense, and hence to eliminate the scope for the use of discretionary power and hence domination. So, courts have emphasised, for example, the special need for certainty in the interpretation of the scope of the criminal law, ${ }^{35}$ and for similar reasons, Ronald Dworkin exempted the criminal law from his general theory of common law interpretation:

In one department, criminal law, Anglo-American practice is very close to unilateralism. We believe that no one should be found guilty of a crime unless the statute or other piece of legislation establishing that crime is so clear that he must have known his act was criminal, or would have known if he had made any serious attempt to discover whether it was...But our legal practice is not unilateralist in this way over the broad reaches of the private law that we have mostly been discussing. ${ }^{36}$

Understandable though it might seem that one would, for republican reasons, wish to support 'unilateralism' in the criminal law, unilateralism is neither descriptively accurate nor morally attractive. It is, for example, frequently necessary and desirable to use open-textured norms such as '(un)reasonable,' '(un)justified,' or (un)warranted' in the definition of criminal conduct, notwithstanding the discretionary element that this introduces into the scope of the criminal law, in the hands of judge or jury. ${ }^{37}$ This is the case when it would be arbitrary, and perhaps even more confusing, to seek to capture the criminal offence through the specification of individual instances of wrongful conduct. ${ }^{38}$

Further, the criminal law must often employ terminology or concepts far removed from lay discourse. It must do this, even though to do so is bound to frustrate any attempt by lay people fully to inform themselves of their obligations in the way Dworkin supposes that they should be able to do. Key parts of the criminal law-the definition of 'property' in theft being an example — are necessarily in part aimed at experts who apply and administer the law, rather than at private citizens. Section 4 of the Theft Act 1968 says that land may only be stolen, inter alia, when the defendant, 'is a trustee or personal representative, or is authorised by power of attorney,

\footnotetext{
${ }^{34}$ Lukes' remarks about the limits of altruism seem pertinent here, even though he is not speaking of assisted suicide cases: 'Even under altruism, there will be a need to protect people from others' mistakes about what altruism requires': Steven Lukes, Marxism and Morality (Clarendon Press, 1985), at 66.

35 Practice Statement (Judicial Precedent) [1966] 1 WLR 1234; Austin v Mayor and Burgesses of the London Borough of Southwark [2010] UKSC 28.

36 Ronald Dworkin, Law's Empire (London: Fontana, 1986), 143, discussed in Jeremy Horder, 'Criminal Law and Legal Positivism' (2002) 8 Legal Theory 221.

37 Jeremy Horder, n. 36 above, at 233-34.

38 Jeremy Horder, n. 36 above. See further, Timothy Endicott, 'The Impossibility of the Rule of Law' (1999) 19 OJLS 1.
} 
or as liquidator of a company, or otherwise, to sell or dispose of land belonging to another.' In so saying, the 1968 Act is speaking principally to the lawyer, prosecutor or judge, rather than to the lay person; but not wrongly, in spite of the fact that Sect. 4 clearly thereby fails the test of clarity set down by Dworkin for a 'unilateralist' (republican) criminal law. Criminal laws are not simply commands aimed at governing citizens, imposing what can be called 'conformity obligations.' Criminal laws must, perhaps principally, serve normatively to empower officials whose obligation it is to interpret and-exercising their discretion appropriately-enforce such laws: what can be called 'compliance' obligations. ${ }^{39}$ As a set of prohibitions, the traditional criminal law constitutes in part a set of declaratory (defining), dutyimposing and power-conferring norms that shape the way in which the protection of 'life and liberty [etc.]' may be upheld by state officials, through the exercise of their discretion.

\section{Preventing Domination and the Goals of the Criminal Law}

It is clear that Pettit supports a broadly liberal-democratic conception of criminal law and justice. For traditionalists working within a liberal framework, Pettit's vision of a republican criminal law is in fact reassuringly familiar. He favours parsimony in the use of the substantive criminal law, ${ }^{40}$ limitations on the powers of the police and prosecutors, ${ }^{41}$ restrictions on judicial discretion in sentencing, ${ }^{42}$ and proportionality in punishment. ${ }^{43}$ There is not much anti-liberal radicalism here. Nonetheless, Petit believes that his account of freedom has significant implications for criminal law theory. As he puts it, '[T]he most crucial idea for a theory of criminalisation is that of equal freedom as non-domination. ${ }^{44}$ This basic contention is shared by Alon Harel, who argues that there is a duty to criminalise invasions of, 'basic rights to life and liberty,' because in the absence of such criminalisation individuals, 'live at the mercy of others. ${ }^{45}$

Is the raison d'être of criminal laws prohibiting murder, rape, pillage, and so on, that they reduce the scope for what Pettit calls, 'particularly egregious forms of dominating interference?' 46 In a basic sense, this might seem to be trivially correct. Surely, without such laws, we would all be at the mercy of the most ruthless and the strongest? True enough. However, it does not follow that the prevention of domination is the principal or most plausible empirical or normative explanation for offences against the person or against property (and so on). To begin with, in Pettit's terms, the criminal law is as much concerned with what he calls 'effective'

\footnotetext{
39 See the discussion in Jeremy Horder, n. 36 above.

40 Philip Pettit, n.3, at 143.

41 Philip Pettit, n.3, at 147.

42 Philip Pettit, n.3, at 148.

43 Philip Pettit, n.3, at 146.

44 Philip Pettit, n.3., at 136.

45 Alon Harel, 'The Duty to Criminalise' (2015) 34 Law and Philosophy 1.

46 Phillip Pettit, n. 2 above, at 139.
} 
republican freedom (unintended obstacles to or interferences with freedom) as it is with formal republican freedom (freedom from domination), and frequently fails quite deliberately to distinguish normatively between the two.

To give a well-worn example, in English law, rape is committed not only when $\mathrm{D}$ intends to have sexual intercourse whether or not $\mathrm{V}$ consents (thereby manifesting the 'will to power' of domination over V) but also when $\mathrm{D}$ has non-consensual intercourse with $\mathrm{V}$ without any adequate basis for believing that $\mathrm{V}$ consents. ${ }^{47}$ In the latter case, the basis for convicting $\mathrm{V}$ is D's (weak or strong ${ }^{48}$ ) indifference to V's consent; but indifference, however devastating the consequences, is not in itself an instantiation of domination, even if those in a position to dominate may be indifferent to the interests of those over whom they hold sway. Pettit may say that all this shows is that, in the case of rape in English law, effective freedom from sexual violation is-rightly - protected alongside freedom from the exercise of formal domination over another's sexual autonomy. The example does not show, Pettit might say, that the evil of 'indifferent' rape is the same kind of evil as the (in principle, greater) evil of intentional rape. Such an analysis is not manifestly mistaken. However, the analysis risks putting the demands of a general theory-'domination is the explanation for serious offences' - ahead of context sensitivity in the analysis of the ways criminal wrongs are constructed. ${ }^{49}$ In that regard, it is strongly arguable that a feature of the wrong in rape is that, unlike some other wrongs such those involved in homicide, it does not change in nature depending on whether D acts intentionally, or by contrast recklessly or negligently. This claim harks back to a question about Pettit's theory raised earlier. ${ }^{50}$ How important really is it, morally, to follow through in law (and politics) on the conceptual distinction between intentional and other ways in which power and control may be exercised over others?

In setting out his stall, Pettit describes his focus in a variety of ways. He says that his theory is concerned with the, 'most plausible' examples of acts that should be criminalised, namely, 'offences that have traditionally counted among ordinary people as criminal...the core of criminal law. ${ }^{, 51}$ These, 'include' fatal and nonfatal offences against the person or property and public order, but are generally to be understand as 'mala in se' or things bad in themselves, 'by regular criteria., 52 Pettit's overriding concern with domination by one individual over another leads

\footnotetext{
47 Sexual Offences Act 2003, s.1(1). For Lacey's discussion of rape, in this respect, see Lacey, 'Unspeakable Subjects, Impossible Rights: Sexuality, Integrity and Criminal Law', (1998) 11 Canadian Journal of Law and Jurisprudence 47; Nicola Lacey, 'Legal Constructions of Crime', in Mike Maguire, Rod Morgan and Robert Reiner (eds), The Oxford Handbook of Criminology, $4^{\text {th }}$ Edition (Oxford: Oxford University Press, 2007), 186.

48 On 'weak' and 'strong' forms of indifference to another's interests, see Jeremy Horder, 'Gross Negligence and Criminal Culpability' (1997) 47 UTLJ 495.

49 See Nicola Lacey, 'Legal Constructions of Crime', n 47 above, 181.

50 See text following n. 13 above.

51 Philip Pettit, n 3. above, at 143.

52 Ibid. For criticism of such a doctrinal starting point in providing an account of criminal law, see Nicola Lacey, Lacey, Nicola (2000) 'Philosophical Foundations of the Common Law': Social not Metaphysical', in Jeremy Horder (ed.), Oxford Essays in Jurisprudence: Fourth Series (Oxford: Oxford University Press, 2000) 17.
} 
to his concentration on offences against the person within the mala in se. But of course, mala in se-things bad in themselves by 'regular criteria'-go much further, and some important wrongs of this type are more difficult to explain in terms of domination. An example is bribery:

X company (based in the UK) instructs its agent, Y (a British national), in Zedland, to secure a contract through bribery, if the need arises. $\mathrm{Y}$ is able to agree a contract with B, a Zedland public official, by offering B a bribe. Although technically an offence, the taking of bribes by public officials is generally overlooked in Zedland, because the practice provides a way in which public officials' take-home pay can be increased without a cost to the public purse.

In this example, under most modern anti-bribery legislation, $\mathrm{X}$ company, its directors, and Y, will all commit serious offences, liable to lead-in the case of the directors and $\mathrm{Y}$ - to substantial terms of imprisonment. Bribery is without question a malum in se, a wrong bad in itself by 'regular criteria.' Yet, it is hard to see wherein lies the element of domination in this example, and the same is true for many other financial crimes that are mala in se, such as false accounting, insider trading or tax evasion.

There are certainly some crimes that directly target the exercise of wrongful domination. The offence in English law of, 'controlling or coercive behaviour in an intimate or family relationship' is an example. ${ }^{53}$ Sex trafficking, and kidnapping (at least in some of its manifestations), are two others. Further, there are the efforts to disrupt the authority of (and ultimately eliminate) certain types of criminal gang and organisation, one of the typical ends of such gangs being to establish unauthorised systems of domination over others ${ }^{54}$; but such examples are the exception rather than the rule. How secure, though, is Pettit's analysis of the more mainstream offences against the person and property, in terms of domination? Pettit says:

[W] hen someone commits a crime they typically present themselves as dominators of the victim: they act in a way that suggests a belief that they can interfere on an arbitrary basis with that person. If you like, they assume a dominating position in relation to the victim. ${ }^{55}$

Pettit is making a descriptive claim, namely that an offence against the person intentionally committed—say, murder — embodies not just the normatively definitive intention to kill (or to cause serious harm), but also a normatively significant belief. This is the belief that the victim's life 'can'-i.e. may permissibly-be ended simply because the killer wishes it. By softening his claim-describing the way he thinks a criminal 'typically' (rather than always) presents themselves-Pettit makes it difficult to say how much theoretical significance we should attribute to the claim. In this, his theory stands in contrast to the more robust neo-Hegelian theory of Alan

\footnotetext{
53 Serious Crime Act 2015, s.76.

54 See, for example, the Serious Crime Act 2007; Criminal Law (Criminal Organisations Disruption) Amendment Act 2013 (Queensland).

55 Philip Pettit, n. 5 above, at 68.
} 
Brudner, for whom, 'desert is understood stringently,' and it is always the case that true or real crime involves an act respecting which, 'the wrongdoer knowingly exercises a degree of freedom inconsistent with the equal freedom of the other. ${ }^{56}$

Even if the weaker nature of Pettit's theory perhaps makes it less vulnerable to attack on the grounds of its inaccuracy as a general description of the criminal law, it remains problematic. What precise role is being played by a wrongdoer's (mistaken) belief that they had a permission to treat a victim in an arbitrary way? It is possible to think of unusual circumstances in which such a belief is normatively active, figuring more or less directly in D's practical reasoning. An instance could be where $\mathrm{D}$ persuades $\mathrm{V}$ to sign a contract that permits $\mathrm{D}$ to beat $\mathrm{V}$ when $\mathrm{V}$ fails to work hard enough (in D's eyes) for D. In such a case, D's belief that he or she is entitled to beat V, when V fails to work hard enough (as D sees it), is likely to be normatively 'active' in any instance in which $\mathrm{D}$ beats $\mathrm{V}$ for such a failure. Perhaps more commonly, such beliefs may be normatively more passive, forming (say) part of a cultural background that has explanatory power in relation to D's conduct without playing a direct causal role in D's practical reasoning. In a patriarchal society, domestic violence may, in spite of being illegal, be quite commonplace and often overlooked by the law enforcement authorities. ${ }^{57}$ Suppose that, in such a society, D loses his temper with and strikes his partner, V, when $\mathrm{V}$ challenges some demand that $\mathrm{D}$ has made of $\mathrm{V}$. It may not be true to say that, in acting, $\mathrm{D}$ has drawn directly on a belief that he is entitled to behave-or should be excused for behaving —in such a violently domineering way. It may nonetheless be true that such a sense of entitlement (to dominate) forms part of the cultural background that explains his loss of temper and its violent outcome.

In the passage cited above, Pettit appears equivocal on the issue of whether the belief in the right to dominate, said to be typically held by a 'true' criminal wrongdoer, is normatively active or passive in relation to the commission of wrongdoing. The suggestion that wrongdoers, 'typically present themselves as dominators of the victim' suggests that the belief is active (making a significant causal contribution), whereas the claim that wrongdoers, 'act in a way that suggests a belief that they can interfere on an arbitrary basis,' seems to lean in favour of regarding the belief as more passive: present, certainly, but not necessarily exercising a direct causal influence. The issue is an important one. Pettit's emphasis on formal domination as a distinct - and greater - political evil than a lack of effective republican freedom implies that a true case of criminal domination must, at the very least, involve direct reliance on a (supposed) permission to dominate the victim. By contrast, the existence of a cultural background that gives an imprimatur to acts that ought to be regarded as impermissible does no more than provide an obstacle, albeit a highly pernicious one, to effective republican freedom. So, the case for saying that the traditional realm of

\footnotetext{
56 Alan Brudner, 'Agency and Welfare in the Penal law', in John Gardner, Stephen Shute and Jeremy Horder (eds), Action and Value in Criminal Law (Oxford: Clarendon Press, 1993), at 32-33.

57 See, generally, Michelle Dempsey, Prosecuting Domestic Violence: A Philosophical Analysis (Oxford: Oxford University Press, 2009).
} 
the criminal law primarily targets domination, rather than being predominantly concerned with barriers to effective republican freedom, is a weak one.

What of the majority of criminal offences, regulatory offences, where there may be no mala in se involved? Pettit seeks to drive a wedge between such offences, and what he regards as truly criminal acts. For him, whereas 'paradigm' offences attract, 'condemnation,' because, 'almost everyone is manifestly disposed to blame perpetrators, ${ }^{58}$ the creation of regulatory offences involves merely what he calls an, 'admission cost' approach. ${ }^{59}$ Under such an approach, behaviour the law wishes to prevent has a cost attached to it - a fine-such that engagement in the behaviour will (if fines are set at the right level) be affordable only to a negligible number of people sufficiently incentivised to engage in the behaviour at the higher cost. The example Pettit gives is the common one of laws imposing fines for parking in a prohibited place. ${ }^{60}$ The implication is, on Pettit's theory, that we do not condemn people for illegal parking, even when they are quite willing to pay the cost of continued transgressions. We simply look to the overall success of the scheme, in terms of a sufficient number of people seeking to avoid such costs by parking elsewhere. In that respect, in practice if not in theory, such schemes might appear to have more in common with the achievement of deterrence through taxation than with the 'traditional' criminal law. What should we make of this distinction?

A threshold difficulty is that Pettit tends to slide between self-regarding and other-regarding accounts of the difference between the types of offence. So, where regulatory offences are concerned, he analyses them in the self-regarding terms of the amoral agent. He says, 'adherents [of the law] treat [criminalisation]...in the manner in which...some people treat parking fines-as costs to be paid for parking illegally.' 61 By contrast, as we have just seen, 'paradigm' crimes are analysed by Pettit in the other-regarding terms of the moral agent, someone 'manifestly disposed to blame perpetrators' for their wrongdoing. ${ }^{62}$ Yet, the choice of one perspective over the other in either case requires justification. Contrary to Pettit's view, (a) the classical economist might argue that we should see condemnation for wrongdoing, feelings of guilt, the pains of imprisonment, and so on, in a self-regarding amoral way as simply costs that may have to be incurred in the pursuit of certain subjectively valued objectives, ${ }^{63}$ and (b) the natural lawyer may argue that when regulatory offences are integral to a valued scheme of co-operation, imposed in the interests of the common good, they carry with them an other-regarding moral obligation of obedience, and so condemnation for breaches (albeit mild condemnation) may be

\footnotetext{
58 Philip Pettit, n. 3 above, at 135.

59 Philip Pettit, n. 3 above, at 134.

60 Philip Pettit, n. 3 above, at 134.

61 Philip Pettit, n. 3 above, at 134.

62 See text at n. 58. For the link between moral blame or condemnation, and treating someone as a moral agent, see the classic article by PF Strawson, 'Freedom and Resentment', in Gary Watson (ed), (1962) 48 Proceedings of the British Academy 1-25.

63 See Richard Posner, 'An Economic Theory of the Criminal Law' [1985] 85 Columbia Law Review 1193.
} 
appropriate ${ }^{64}$ Arguably, it is better to take the other-regarding perspective of the moral agent for the purpose of analysis in both cases, whether one's approach is broadly supportive of criminal justice institutions, ${ }^{65}$ or highly critical of them. ${ }^{66}$

Further, Pettit's presentation of 'paradigm' crimes in terms of wrongdoing that attracts citizens' condemnation sits uneasily alongside his contention that the wrongdoing typically instantiates domination. People living under benign domination may - albeit wrongly - come to value (say) the judgment of the dominant person or people concerning their best interests, and hence fail to condemn the domination. Contrariwise, people may wrongly condemn conduct as worthy of criminalisation, as under the Uganda Anti-Homosexuality Act 2014, when it is not. Quite simply, it is unhelpful to tie a theory of criminalisation too tightly to the practice of condemnation. ${ }^{67}$ In some cases, widespread condemnation of seriously wrongful conduct may help to reinforce the moral case for criminalisation and for vigorous enforcement of the law. But equally, in other cases, such condemnation may, by (say) demonising certain types of offenders, make fair and proportionate enforcement hard to achieve without simultaneously exposing offenders to disproportionately hard treatment at the bar of public opinion. ${ }^{68}$ Contrariwise, an absence of public condemnation of conduct may mean that police and prosecutors struggle to make perfectly sound laws targeting significant wrongs achieve their legitimate deterrent and retributive aims, as in — for example—-many cases of copyright infringement.

In the case of regulatory offences, Pettit's analysis of such examples, as ones in which the law and offenders alike see them in terms of cost-benefit analysis, is distorted by his assumption that the fine-or analogous form of cost—is the only remedy appropriate for these offences; but this is not so. A number of significant activities, such as driving, require a licence if one is to engage in them lawfully, and loss of one's licence may be a powerful sanction. A company director may also be disqualified from acting, if found guilty of misconduct. ${ }^{69} \mathrm{~A}$ business may find itself struck off the register of companies, if it fails to file accounts (and ignores subsequent warnings). ${ }^{70}$ Under the UK's Immigration Act 2016, a business with a history of employing illegal workers may be closed down by the enforcement authorities. Such sanctions are only artificially regarded as a mere 'cost,' to be factored into a decision whether to continue with illegal activity regardless. They-quite deliberately - threaten the viability of engaging in the relevant business activity at all. Such examples illustrate the pointlessness of attempts to draw stark theoretical or

\footnotetext{
${ }^{64}$ See e.g. John Finnis, 'The Authority of Law in the Predicament of Contemporary Social Theory' (1984) 1 Notre Dame Journal of Law Ethics and Public Policy 115.

${ }^{65}$ See, e.g. the approach of AP Simester and Andreas Von Hirsch, Crimes, Harms and Wrongs: On the Principles of Criminalisation (Oxford: Hart Publishing, 2011).

${ }^{66}$ See e.g. Steven Lukes, n. 34 above, ch 4.

${ }^{67}$ See Nicola Lacey, 'Legal Constructions of Crime', n 47 above, 183-184.

${ }^{68}$ An example might be prosecution of the crime of infanticide against mothers.

${ }^{69}$ Company Directors Disqualification Act (UK) 1986.

${ }^{70}$ Companies Act (UK) 2006, s.1000, as amended by the Small Business, Enterprise and Employment Act 2015, s. 103.
} 
practical contrasts between 'real' and 'regulatory' offending. As Lacey has consistently demonstrated, the grey area between the two is too large for that. ${ }^{71}$

\section{Republican Freedom, Liberal Freedom and Criminal Law}

I will conclude with some reflections on the relationship between Pettit's republicanism and liberal political theory. For Pettit:

Citizenship gives protection and constitutes freedom only so far as the law is appropriately framed, respected, and applied... [C]itizenship amounts to freedom only... in a society where cultural and institutional pressures are such that even if people are not always lovers of the good, still they can be relied upon to do their bit in the civic realm... ${ }^{72}$

Freedom as non-domination is not, thus, a matter solely of law in the books. There must also be official action in accordance with declared rule, ${ }^{73}$ and more broadly and importantly, a culture sustained by citizens themselves in which the knowledge and exercise of freedoms is learned, valued, supported and promoted. In a republican spirit, for example, one should ask not just of the substantive law but also of the culture of law enforcement: is it, say, unacceptably authoritarian or patriarchal (a public negative), ${ }^{74}$ or on the contrary informed by a healthy respect for 'anti-deference' (a public good)? ${ }^{75}$

There is no doubt that, on occasion, law reform is influenced by such considerations. In 2009, the UK Parliament abolished criminal defamation, and in 2013, it abolished the criminal prohibition on engaging (without more) in 'insulting' behaviour in public in England and Wales. ${ }^{76}$ The removal of these prohibitions was intended to enhance the protection of citizens' freedom of expression, reducing the fear of falling foul of the criminal law just because other people-including agents of law enforcement-were liable to take offence at someone's robust outspokenness. ${ }^{77}$ The removal of the prohibitions was thus designed, in Pettit's terms, to enhance people's prospects for enjoying a, 'mutually reinforcing consciousness of enjoying...independence. ${ }^{78}$ This latter feature of republican theory, largely lost in much of modern political culture, originally had a firm basis in the English

\footnotetext{
71 See Nicola Lacey, 'Criminalisation as Regulation: the Role of the Criminal Law', in C Parker et al. (eds), Regulating Law (Oxford: Oxford University Press, 2004) 144; 'Jeremy Horder, 'Bureaucratic “Criminal” Law: Too Much of a Bad Thing?', in RA Duff et al. (eds), Criminalisation: The Political Morality of the Criminal Law (Oxford: Oxford University Press, 2014).

72 Philip Pettit, n. 4 above, at 312.

73 See further Lon Fuller, The Morality of Law (New Haven: Yale University Press, 1964).

74 For two excellent discussions in different contexts, see Markus Dubber, The Police Power: Patriarchy and the Foundations of American Government (New York: Columbia University Press. 2005); Michele Dempsey, n. 57 above. On public negatives and criminal law, see Jeremy Horder (ed), n. 22 above.

75 Vincent Chiao, n. 13 above, at 105-106.

76 Respectively, Coroners and Justice Act 2009, s.73, and Crime and Courts Act 2013, s.57.

77 http://www.cps.gov.uk/legal/p_to_r/public_order_offences/\#Section_5.

78 Philip Pettit, n. 3 above, 138.
} 
'common mind.' As FW Maitland observed, when speaking of ordinary people's belief in local or customary law administered by the Justices (as compared with law promulgated and adjudicated upon centrally):

Englishmen have trusted the law; it were hardly too much to say that they have loved the law; but they have not loved and do not love lawyers, and the law that they have loved they did not think of as lawyers' law... [it was] the voice of law [in the mouth of] many a country squire whose only juristic attainment was the possession of a clerk who could find the appropriate page in Burn's Justice. ${ }^{79}$

This dimension to republican theory is arguably its most distinctive contribution to social and political theory. In sophisticated liberal political theories, it is recognised that the value-indeed, the very possibility — of a personally autonomous life, depends on the existence of thriving social institutions and on the participation of others in lives in common. ${ }^{80}$ Generally lacking in liberal theory, though, is an account of how a liberty-loving political culture, embodied in both individual and common thought and practice, makes an essential contribution to the common weal.

Even so, Pettit's republican theory of freedom should be regarded as in this respect supplementing, rather than challenging, sophisticated liberal theories of freedom focused on personal autonomy. ${ }^{81}$ What Pettit's theory adds is a theory of what it means to enjoy 'political' autonomy, alongside personal autonomy. In other words, to play one's full part in a republican state is to be able-on the same basis as others, and in appropriate circumstances in combination with them-to engage in valuable political activity, as oneself (part) author of that activity.

The suspicion that Pettit's theory is indeed autonomy focused, and hence essentially liberal in orientation, comes in the following passage (very similar to the one in which Finnis criticised domination, years ago ${ }^{82}$ ), where he emphasises the impact that domination threatens to have on one's choices in life, large and small:

Being dominated involves occupying a position where another can interfere on an arbitrary basis in your life: specifically... where another can interfere with greater or lesser ease on a more or less arbitrary basis across a smaller or larger range of choices. ${ }^{83}$

Theoretically, this position appears to map quite closely on to Joseph Raz's view that, to use Raz's own example, where I must share life on a small island largely devoid of secure shelter with a wild tiger, I will lack autonomy, because my life will be effectively ruled by the need to avoid the potential threat. ${ }^{84}$ The point is not

\footnotetext{
79 FW Maitland, 'The Shadows and Silences of Real Life', in HAL Fisher (ed), The Collected Papers of Frederick William Maitland (Cambridge: Cambridge University Press, 1911), vol I, at 476-77.

${ }^{80}$ See, generally, Joseph Raz, The Morality of Freedom (Oxford: Oxford University Press, 1986).

81 See Joseph Raz, n. 80 above. In that respect, Pettit has simply overlooked the ways in which modern liberal theory had already moved on - at the time Pettit was writing-from understanding liberty in terms of Berlin's over-simplistic contrast between negative and positive liberty.

${ }^{82}$ See text at n. 21 above.

83 Philip Pettit, n. 3 above, at 341.

84 Joseph Raz, n. 80 above, at 374.
} 
necessarily that, in this situation, I cannot make valuable choices of any kind ${ }^{85}$ The point is simply that the threat hanging over me deprives me of the chance for a fully autonomous life, a life that includes stable long-term commitments and plans for worthwhile personal development, alongside valuable day-to-day decisions. For Pettit, of course, Raz's example should not be compared with one involving domination, because the impact of the tiger's threat is to deprive one of effective republican freedom, not formal republican freedom. Even so, Raz's liberal account of how one may come to lack freedom has crucial advantages over Pettit's domination-focused theory.

To begin with, there is an important ambiguity about the wrong of domination. Is what makes domination qualitatively worse than other kinds of loss of freedom simply the fact that $\mathrm{X}$ has an unconstrained power over $\mathrm{Y}$ ? Alternatively, is it the case that, in order to identify the wrong in domination, must one conjoin with $X$ 's unconstrained power over $\mathrm{Y}$ an assumption that the power also impinges on Y's life, 'across a smaller or larger range of choices, ${ }^{, 86}$ in unacceptable ways? Let me expand on this point. Alongside his 'slave' example_where, clearly, a master will have unconstrained power over almost every dimension of the slave's life-Pettit includes examples in which an employee or debtor, 'lives under the thumb' of the employer or creditor respectively. ${ }^{87}$ It is, of course, a commonplace that, as your employer or creditor, I may well be able to demand that you work, or pay your debt, when it is convenient for me but highly inconvenient-possible, even ruinous-for you to do so. So, it is unclear where the wrong lies in the employer or debtor having the relevant power. It may be that what Pettit has in mind when speaking of the wrong in such cases is a situation in which, such is the hold that the one has over the other that, in effect, the employer or creditor controls much of the employee or debtor's life. This would be a disproportionate control relative to the relationship in question, a point brought home to Charles Dickens when his father was imprisoned for debt.

Such an analysis, though, would make the wrong in domination turn, in part, on an evaluation of nature and degree of control that the power confers. That kind of analysis runs counter to the formal nature of the domination to which Pettit objects: any cases where the nature of the power I have over you is such that I can exercise it to please myself, or to prefer some 'alien interest, ${ }^{, 88}$ to your interests. Yet, this appears to rule out almost all significant employer-employee or debtor-creditor relationships (even for as little as $£ 1$ ), as forms of exploitative domination, because Pettit does not provide a theory of justified, intentional use of power over another. ${ }^{89}$ In other words, he does not explain how, if at all, employer-employee or debtor-creditor relationships (amongst others) can serve the interests of employees or debtors,

\footnotetext{
${ }^{85}$ It may be that, unbeknownst to me, the tiger would rather die than have to attack and eat me, and so (without knowing it) I could in fact enjoy a fully autonomous life, in so far as life on such an island allows for that.

86 See passage cited at $n .83$ above.

87 Philip Pettit, n. 5 above, at 64-65.

88 See text at n. 5 above.

89 Beyond suggesting that such a power can be justified if the power serves only the interests of the person over whom it is held. See text at n. 4 above.
} 
even though those relationships allow the employer or creditor some control over the employee or debtor that can be exercised, 'according to their own arbitrium. ${ }^{, 90}$

An analysis of such cases in terms of personal autonomy provides a simpler way in which to understand their (un)justifiability, because it is not tied to a distinction between form and substance in the manner of Pettit's domination theory. Properly regulated employer-employee and debtor-creditor relationships are social forms capable of providing a setting in which both parties can enhance their personal autonomy. It is, of course, a different matter if these relationships edge into vehicles for exploitation, as in the case of 'extortionate' credit bargains, 91 'aggressive' selling practices (when the criminal law may come in ${ }^{92}$ ) or many kinds of 'zero hour' employment contracts. Even so, the movement from an autonomy-enhancing to an autonomy-reducing relationship of this kind is best understood as one of degree. It involves a substantial grey area, in which the existence of formal domination comes to be perceived as wrong only when - to an extent it will be hard to clarify in advance, as in the examples just given-it also involves a lack of effective republican freedom. Our understanding is not helped by starting from the proposition that all such relationships are presumptively ones of unjustified domination.

That brings me to the general justification in Pettit's theory for state institutions, like criminal law and punishment. Does the republican perspective on these institutions add something distinctive, not found in liberal theory? Pettit says:

The interests which a republican state ought to track are interests that each shares...with others...And so penal interference will be non-arbitrary, and saliently non-arbitrary, so far as it tracks interests that the offender shares with others...in accordance with shared ideals. It will [then] be non-arbitrary...even when the pursuit of those interests means frustrating the wish of the offender to be given a special deal ${ }^{93}$

This shared interest-based argument does not appear to have a special connection with the institutions of criminal justice. It seems to be an argument apt to support any state institutions which help us to achieve common goals that cannot adequately be achieved through the mere aggregation of individual actions. State-enforced systems of taxation are an example. Pettit's argument is really another way of saying that state institutions, including law (and hence the institutions of criminal justice), can-depending on why and how they act-exercise legitimate authority. Such an argument is perfectly consistent with a liberal account of the legitimacy of state institutions; but Pettit considerably underplays the complexity of explaining legitimate authority in this respect.

In the passage just cited, in his contrast between acting on interests in 'shared ideals,' whilst frustrating any given individual offender's interest in a 'special deal,' Pettit seems to be alluding to the way that the state can act authoritatively in solving

\footnotetext{
90 See text at n. 5 above.

91 Consumer Credit Act 1974, ss. 137-138.

92 The Consumer Protection from Unfair Trading Regulations (UK) 2008, s. 7.

93 Philip Pettit, n. 5 above, at 73.
} 
prisoners' dilemma situations. These are situations in which everyone has an interest in a common solution, and no interest in abandonment of the common solution, but the best deal for any given individual is that others follow the common solution whilst he or she receives special treatment. ${ }^{94}$ Through adequately incentivisingand if need be, coercing - people into following the common solution, the law acts with legitimate authority in removing or substantially reducing the temptation for any given individual actively to seek the 'best' solution for themselves. Yet, there are a number of other bases on which the law may claim legitimate authority. Raz, for example, discusses five in all. ${ }^{95}$

One example is the need to co-ordinate conduct, even in circumstances where there is no prisoner's dilemma, because there is no particular incentive to seek a special deal for oneself. A frequently cited example involves the rules of the road. We all have an interest in certain common road traffic solutions, such as a clear determination of which side of the road to drive, where it would make little sense for someone to seek a special deal for themselves (given the need to co-ordinate their conduct with others). Another example is the requirement for political parties to publish election spending accounts in a specified form, imposed - on pain of criminal penalty for breach—by Sect. 47 of the Political Parties, Elections and Referendums Act 2000. In this case, there is a common interest in the accounts of all parties being published in the same form, so that they may easily be compared, but no political party has an interest in a special deal relaxing the requirements of the common solution, because such a special deal would risk impairing the public's perception of that party's financial probity. The function of the criminal law in such cases is to ensure that the common solution remains 'common,' and is not abandoned through the agreement of affected parties, through misunderstanding, neglect, or otherwise.

Another of Raz's examples of the need for law's authority was long ago foreshadowed by Blackstone, one of Pettit's 'republican' thinkers. ${ }^{96}$ This is where there is a risk that—in the absence of legal restraint—people may feel empowered to act with a self-centred disregard for others' key interests, not least when they themselves believe they have been wronged. As Blackstone put it:

In a state of society this [natural] right [to punish] is transferred from individuals to the sovereign power; whereby men are prevented from being judges in their own causes, which is one of the evils that civil government was intended to remedy.... [The magistrate]...bears the sword of justice by the consent of the whole community. ${ }^{97}$

Blackstone may have given us no reason for thinking that the 'right to punish' really is a right possessed in the state of nature, and surrendered to the forces of law and order, for so long as the latter endeavour to, 'do right to all manner of people after the

\footnotetext{
94 See the discussion in Scott Shapiro, 'Authority', in Jules Coleman and Scott Shapiro, The Oxford Handbook of Jurisprudence \& Philosophy of Law (Oxford: Oxford University Press, 2002), at 406.

95 See Joseph Raz, n.80 above, at 75.

96 See e.g. Philip Pettit, n. 5 above, at 60.

97 Sir William Blackstone, n. 9 above, vol iv, at 7-8.
} 
laws and usages of this realm, without fear or favour, affection or ill will. ${ }^{98}$ Even so, the need adequately to deter people from acting as 'judges in their causes,' when their actions impinge on the vital interests of others, is real enough.

The justification for the authority of the criminal law is not just 'top-down,' in the manner of the justifications just given. It is also 'bottom-up,' both absolutely-in relation to the existence of the law in general - and contingently, when it is sought to enforce it on particular people or groups in particular circumstances. As Niki Lacey has put it:

[I]t is the underlying bedrock of social support for criminal law which underpins the widespread voluntary compliance without which the hierarchical regulatory resources of the criminal process at the monitoring and enforcement levels would be entirely incapable of delivering the most modest of regulatory objectives. ${ }^{99}$

There is, perhaps, little here with which Pettit would disagree. Even so, he has more work to do to show that we should prefer his analysis of freedom, and the foundations of the criminal justice system, to a liberal account.

For Pettit, in discussing their conception of freedom, 'liberals after Bentham came to care only about coercion of the body or will, ${ }^{100}$ and hence ignored the republican political heritage that should have enriched that conception. That suggestion almost wilfully overlooks the richer conceptions of freedom being developed by liberals, in the century between the writings of TH Green (through Isaiah Berlin) and Joseph Raz. With varying degrees of sophistication, those conceptions sought to plot a course between, and perhaps to draw something from each of, the Benthamite focus on the mere absence of coercion, and the equation of freedom with engagement in feelings and activities that one (rationally) ought to find liberating. In Pettit's theory, thus, one gains no sense of the relevance of, for example, incommensurability to the way in which this course is plotted (a major concern for Berlin), or of the state's role in ensuring-through its own direct actions or through support for voluntary bodies - that there is an adequate range of valuable options and worthwhile activities for citizens (a concern for Green and Raz). On Pettit's theory, such concerns are left unaddressed because they have been largely relegated to the domain of effective republican freedom. One task undertaken here has been to show, with a particular but not exclusive focus on the criminal law, that the distinction between formal and effective republican theory does not have the moral and legal significance that Pettit attributes to it. Consequently, in the light of the foregoing discussion, we have no reason to prefer Pettit's republicanism to those richer, liberal accounts of freedom.

Open Access This article is licensed under a Creative Commons Attribution 4.0 International License, which permits use, sharing, adaptation, distribution and reproduction in any medium or format, as long as you give appropriate credit to the original author(s) and the source, provide a link to the Creative

\footnotetext{
98 The judicial oath: https://www.judiciary.gov.uk/about-the-judiciary/the-judiciary-the-governmentand-the-constitution/oaths/.

99 Niki Lacey, n. 71 above, 150.

100 Philip Pettit, n. 4 above, at 341.
} 
Commons licence, and indicate if changes were made. The images or other third party material in this article are included in the article's Creative Commons licence, unless indicated otherwise in a credit line to the material. If material is not included in the article's Creative Commons licence and your intended use is not permitted by statutory regulation or exceeds the permitted use, you will need to obtain permission directly from the copyright holder. To view a copy of this licence, visit http://creativecommons.org/ licenses/by/4.0/.

Publisher's Note Springer Nature remains neutral with regard to jurisdictional claims in published maps and institutional affiliations. 